\title{
The Game Making Framework for Collaborative Learning
}

\author{
Aprilia Ratna Christanti ${ }^{1}$, Ridwan Sanjaya ${ }^{2}$, Erdhi Widyarto ${ }^{3}$ \\ Information Systems Department, Faculty of Computer Science \\ Soegijapranata Catholic University, Semarang, Indonesia \\ 13070029@student.unika.ac.id ${ }^{1}$,ridwan@unika.ac.id², erdhi@unika.ac.id ${ }^{3}$
}

Abstract - Collaborative learning is a study group process that each member contributes their idea, information, experience, skill, and ability they have so it can be used on learning activity and improve members' knowledge[1]. Digital game can become one of collaborative learning media that is not just for entertainment but also can be used as a unique and effective interactive learning media[2]. In conventional game making for collaborative learning, the research proves that it can improve excitement and contribution in learning activities[3]. But in game making, there are many technical issues for non-computer science students[3]. Based on many issues, designing framework is chosen to become a solution to help people in developing game as collaborative learning media by themselves. Because framework is a basic form of system [4], consist of various command, function, and benefit for developer in application development [5][6], so game making for collaborative learning is conducted again with support from framework designed by researcher. In order to know the effect from framework support in game making as collaborative learning media, this study is based on two subjects of non-computer science students and computer science students.

Keywords - Framework, game making, collaborative learning, computer science students, non-computer science students

\section{INTRODUCTION}

There are many implementations of collaborative learning model in education whether in the nationwide or international, in order to improve human resource quality. Human resource that has quality supports the growth of technology and social economy of a nation[7]. It refers to UNESCO mission in Global Education Monitoring that education changes life and as the heart in building peace, lowering poverty, and having sustainable development[8].

Collaborative learning becomes a new method in education to improve both soft and hard skill in same time, because it's done in group which is every member contributes to solve a problem[9]. Digital game is one kind of digital media that can be developed for collaborative learning[3]. Because digital game can be used just not for entertainment, but it can be used as a unique, interactive, and effective learning media[10].

In a research called "Developing Educational Game for collaborative learning”, it already examines the effective of collaborative learning method via making game in group[3]. Making game together proves to increase student excitement and contribution in learning activity[3].

In game making process for collaborative learning, there are some technical issues for common people[3]. The issues are including installation process, using game engine application, sharing the project 
manually using flash disk, and performing inefficient task assignment by using only one PC each group.

Therefore, the framework design that the researchers developed is chosen as a solution to help common people in making game as collaborative learning media by them. Because framework is known for have various advantages for developer to ease an application development[5]. The framework making process is already published in journal titled "Game Making Framework Development for Collaborative Learning", and framework that already developed named "RPG Maker Game Making Kit” (abridged as RPGMGMK)[11].

This paper will discuss whether any comparisons of framework usage based on user between computer science students with noncomputer science students.

\section{THEORETICAL FOUNDATION 2.1 Collaborative Learning Method}

Learning method is a systematical plan to achieve the goal of learning itself with the appropriate step referring to series of related and progressive acts done by teacher and students[12]. There are some learning methods that effectively improve students' engagement that is cooperative learning, collaborative learning, problem-based learning, inquirybased learning, peer-learning and team learning.

Collaborative learning is one method of active learning registered in GAISE (The Guidelines for Assessment and Instruction in Statistics Education) of the ASA (American Statistical Association) in 2010 (recommendation number 4) which states that[9]:

"Using active learning methods in class is a valuable way to promote collaborative learning, allowing students to learn from each other. Active learning allows students to discover, construct, and understand important statistical ideas and to model statistical thinking. Activities have an added benefit in that they often engage students in learning and make the learning process fun. Other benefits of active learning methods are the practice students get communicating in the statistical language and learning to work in teams. Activities offer the teacher an informal method of assessing student learning and provide feedback to the instructor on how well students are learning. It is important that teachers not underestimate the ability of activities to teach the material or overestimate the value of lectures, which is why suggestions are provided for incorporating activities, even in large lecture classes. " (p. 18).

Collaborative learning is one of learning methods that can make every member in group to actively engage and contribute in class[13]. Collaborative learning needs teamwork within learning process toward the goal of the group. This involves students to teach each other, students teach teacher, and vice versa. It's more important that students have responsibility, actively contribute, and help each other in learning process, so they can achieve their goals in understanding the learning material[14].

According to Smith \& MacGregor (1992) collaborative learning helps student to study more effectively because it covers the aim of education agenda which related each other that is[13]:

a. Involvement (involvement in learning, involvement with other students, and involvement with environment).

b. Cooperation and Teamwork (in a collaborative attempt, students will face differentiation, and must argue in group. This develops capacity to tolerate or resolve differentiation to respect all opinion within group).

c. Civic Responsibility (with dialog, discussion, and consensus form many 
strong opinions inside collaborative learning structure and within society)

\subsection{Digital Game for Learning Media}

Digital game is one of multimedia that can be used not just for entertainment only, but also as an interactive, unique, and effective learning media[2].

According to Salem in game article within journal titled "Will Gaming Save Education, or Just Waste Time?" published by THE said that "Game is rich with data" means that game is full of information for player how to do, where to go, how they can play better. That data can be used by both teacher and students to open scoring, so students really have many data by playing it[15].

\subsection{Framework}

Framework is basic concept of an object oriented application development[16]. It consists of command and function in order to ease developer in application development[6]. Framework usage itself has become common, multiple platform framework development has become a sign that framework evolves and one of local frameworks made by Indonesia is panada framework [17].

These are the four benefits using framework[5]:

o Modularity: help stabilize program when implemented.

o Reusability: reuse component or old command in application to new application so there is no need to make it new all over again.

o Extensibility: easy to add new feature to existing application.

o Inversion of control: stabilize application with calling fast and correct function in application.

\section{METHODS}

This research was conducted by handing out questionnaires of closed and open questions directly to 20 students of Game Technology, Computer Science Faculty and 10 students of English literature, Language and Faculty in Soegijapranata Catholic University. 30 students participated as respondents and participants in Workshop to Create a Game using RPG Maker MV for Collaborative Learning with Framework 'RPG Maker Game making Kit'.

Sample in this research includes 2 subjects consist of students from computer science and non-computer science faculty to find any comparisons from usage of 'RPGMGMK' framework as supporting tools when making game in group. In this workshop, there is a template that already prepared to ease the game making.

Questionnaires were distributed in 3 parts: first part about the respondents, second part 14 closed questions, and third part 4 open questions. These questionnaires were designed to get both respondents' opinion about effect from RPGMGMK framework usage that already developed to help making game as a collaborative learning media.

\section{SURVEY RESULTS}

After the questionnaires were submitted and processed, the result in open question that was:

1. $15 \%$ (3 from 20 of computer science students) and 30\% (3 from 10 of noncomouter science students) said they were very hapy. 65\% (13 from 20 of computer science students) and 70\% (7 from 10 of non-computer science students) said they were very happy making game togheter. 


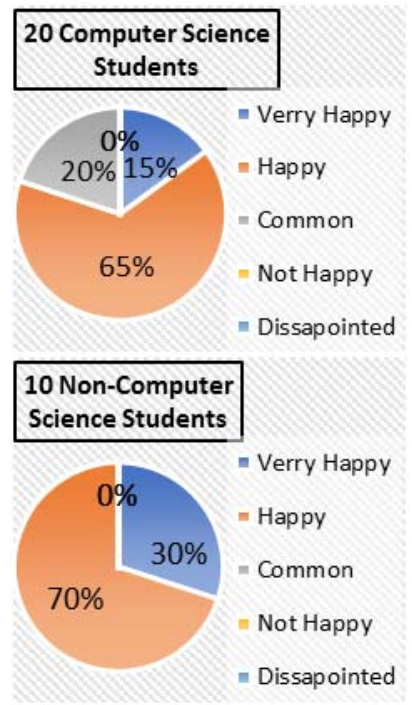

Fig. 3.1 Percentage of happiness making game together

2. $20 \%$ (4 from 20 of computer science students) and 40\% (4 from 10 of noncomputer students) said they strongly agreed. Plus 65\% (13 from 20 of computer science students) and 50\% (5 from 10 of non-computer science students) agreed if using game for learning together.

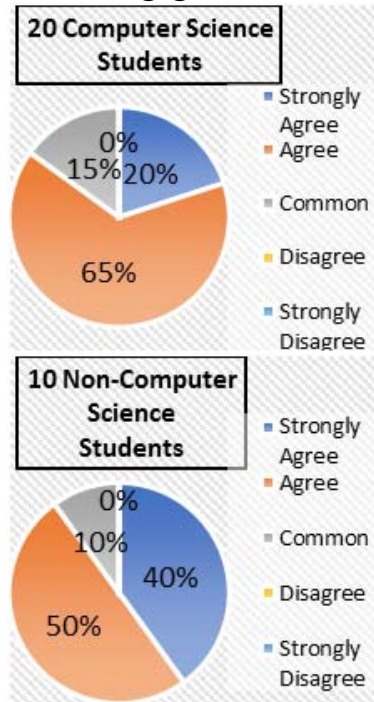

Fig. 3.2 Percentage of how much respondents are agree using game for learning together

3. $25 \%$ (5 from 20 of computer science students) and 9\% (1 from 10 of noncomputer science students) said it was very helpful. Plus 45\% (9 from 20 of computer science students) and $82 \%$ (9 from 10 of non-computer science students) said it was helpful using framework developed by researchers to make game together.

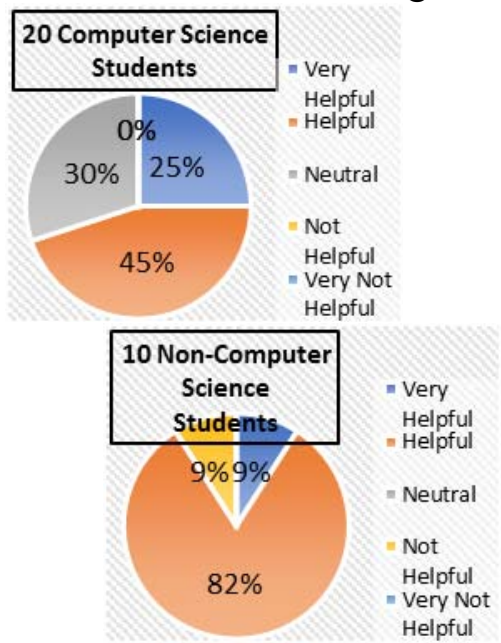

Fig. 3.3 Percentage of framework utilization that developed by researcher to help game making.

4. $10 \%$ (2 from 20 of computer science students) and $20 \%$ (2 from 10 of noncomputer science students) were very excited. And 45\% (9 from 20 of computer science students) and $80 \%$ (8 from 10 of non-computer science students) were very excited when using game for study together with framework support.

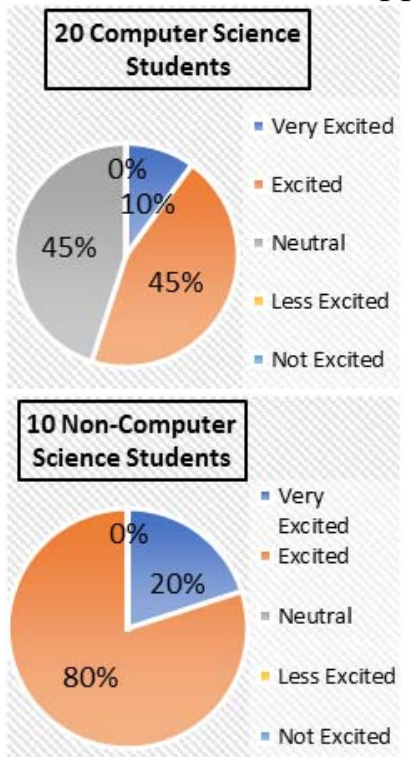

Fig. 3.4 Percentage of study excitement with making game together learning method

5. $10 \%$ (2 from 20 of computer science students) said it was very easy, plus $60 \%$ (12 from 20 of computer science students) 
and $50 \%$ ( 5 from 10 of non-computer science students) said it was easy.

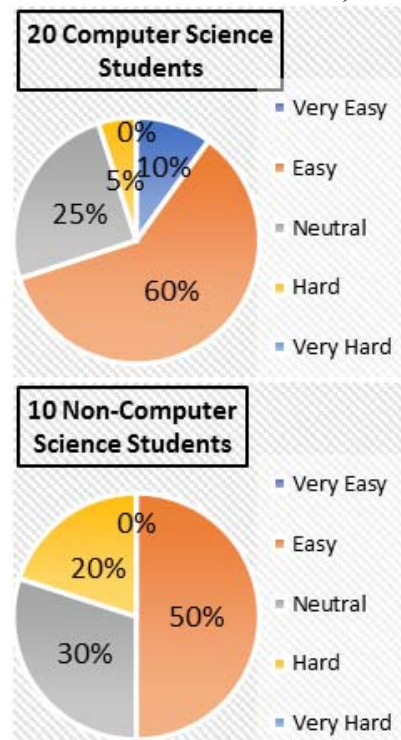

Fig. 3.5 Difficulty of features utilization inside framework

6. $5 \%$ (1 from 20 of computer science students) said that the features inside framework application prepared for making game were very satisfied and 35\% (7 from 20 respondents) said were statisfied. Therefore $80 \%$ ( 8 from 10 of of noncomputer science students) was satisfied.

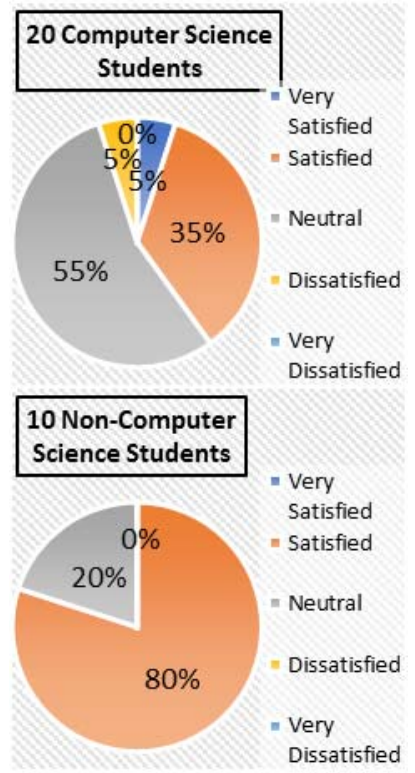

Fig. 3.6 Percentages of available features fulfillment in game making
7. $15 \%$ (3 from 20 of computer science students) and $10 \%$ ( 1 from 10 of noncomputer science students) said it was very helpful. And 65\% (13 from 20 of computer science students) and $60 \%$ (6 from 10 of non-computer science students said automatic installation that was available for making game together helpful.

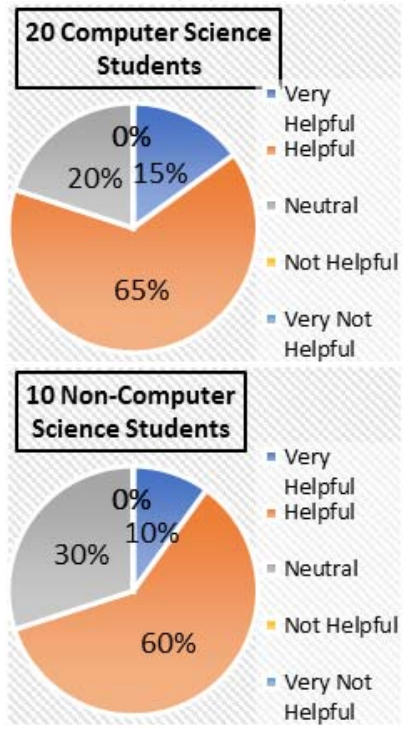

Fig. 3.7 Percentages of automated installation features usage in game making

8. $28 \%$ (6 from 20 of computer science students) and $10 \%$ (1 from 10 of noncomputer science students) said it was very easy. Plus $62 \%$ (13 from 20 of computer science students) and 90\% (9 from 10 of non-computer science students) said that add member feature that was available in framework was easy. 


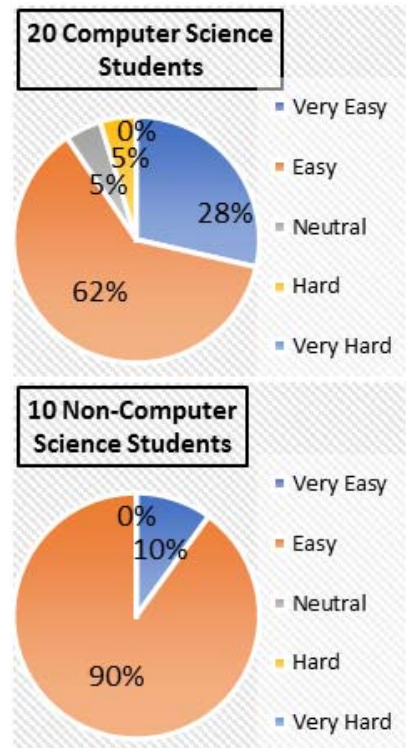

Fig. 3.8 Percentage of add member feature difficulty inside framework

9. $15 \%$ (3 from 20 of computer science students) and $10 \%$ (1 from 10 of noncomputer science students) said it was very helpful. And 65\% (13 from 20 of computer science students) and 70\% (7 from 10 of non-computer science students) said that editing features like upload, download, delete, and synchronize for making game together was helpful.

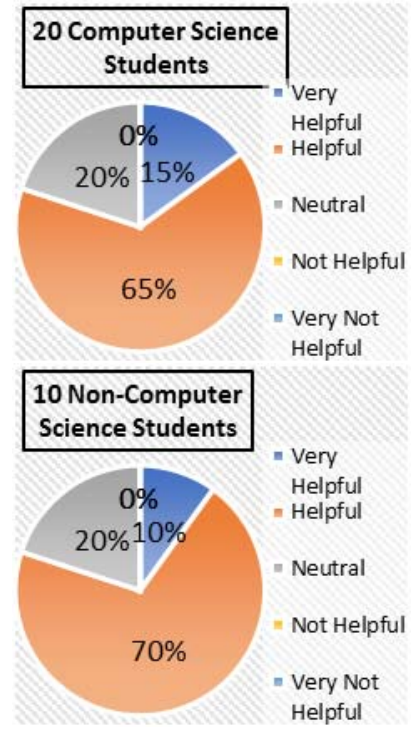

Fig. 3.9 Percentage of file management difficulty (upload, download, delete, and synchronize)

$10.10 \%$ (2 from 20 of computer science students) and $10 \%$ (1 from 10 of non- computer science said game templates that were already provided in game development were very helpful. And 65\% (13 from 20 of computer science students) and $80 \%$ ( 8 from 10 of non-computer science students) were helpful.

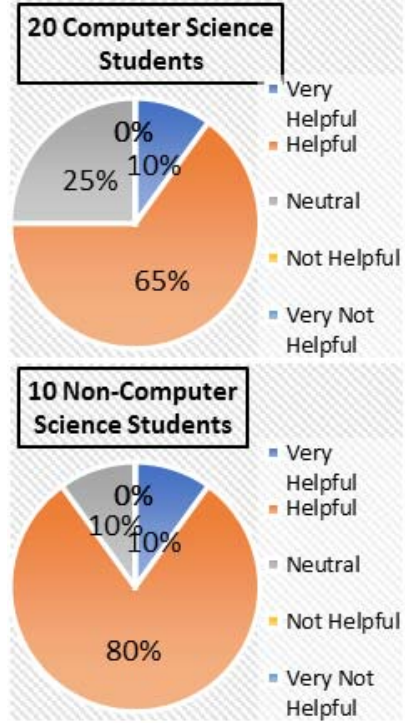

Fig. 3.10 Percentage of how helpful is the prepared template for making game together

$11.5 \%$ (1 from 20 of computer science students) and $10 \%$ (1 from 10 of noncomputer science students) were very interested. Plus 55\% (11 from 20 of computer science students) and 70\% (7 from 10 of non-computer science students) were interested to making game together with framework support. 


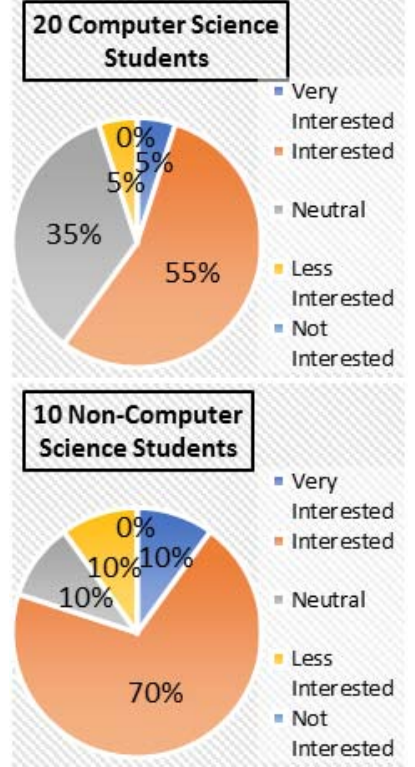

Fig. 3.11 Percentage of students' interest in making other game with framework support

$12.15 \%$ (3 from 20 of computer science students) and 30\% (3 from 10 of noncomputer students) were very interested. $55 \%$ (11 from 20 of computer science students) and $60 \%$ (6 from 10 of noncomputer science students) were interested if RPG game they made can be played on tablet or smartphone.

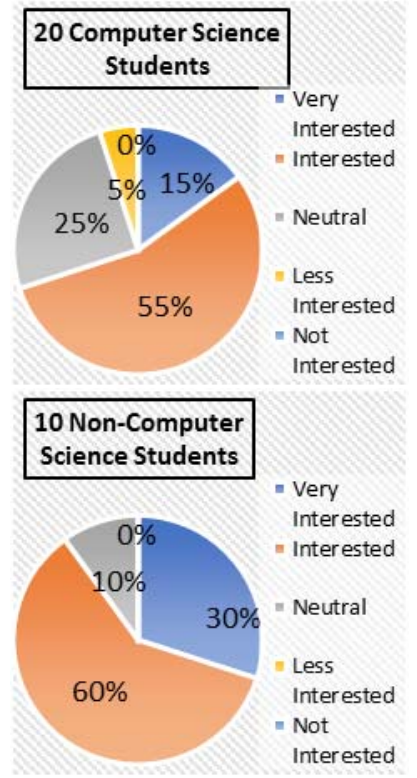

Fig. 3.12 Percentage of interest in game they make can be played on gadget

$13.15 \%$ (3 from 20 of computer science students) said often using Dropbox, otherwise $60 \%$ (12 from 20 of computer science students) rarely using Dropbox. $10 \%$ (1 from 10 of non-computer students) were very often using Dropbox and 40\% (4 from 10 of non-computer students) were often using Dropbox.

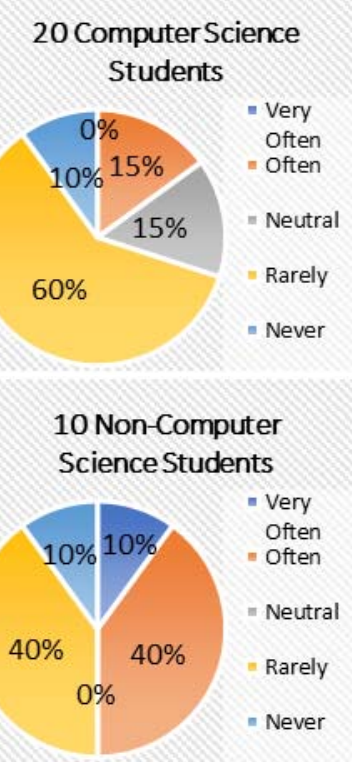

Fig. 3.13 Percentage of Dropbox usage

$14.30 \%$ (6 from 20 of computer science students) said cloud storage usage as game project file was very easy and $45 \%$ ( 9 from 20 of computer science students) said was easy. The same opinion was said by $70 \%$ (7 from 10 of non-computer user).

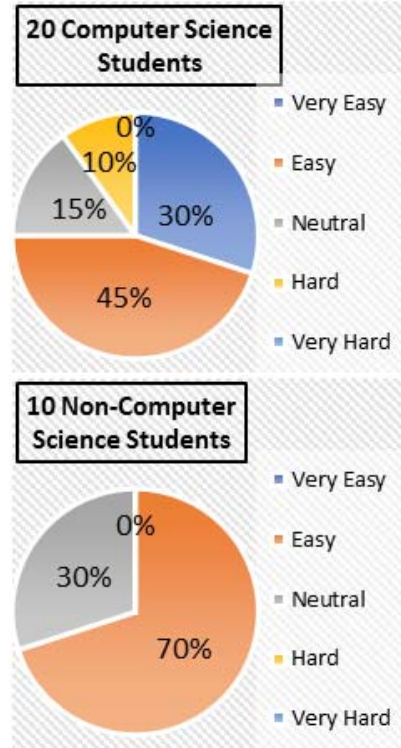

Sisforma vol.4 no.2 November 2017 : 6-14 
Fig. 3.14 Percentage of difficulty using cloud storage as main storage

Next, the answer of open questions from both subjects, the first question is about the weakness from RPGMGMK framework. The framework needed to be more developed, so the installation progress would be faster, then stable internet was needed for fast data sync, overwrite data that could not be changed to previous version.

Second, framework features that eased the game development was an open template game that was provided after installing the framework, easy file sharing management (upload, download, delete and file sync), RPG and Dropbox Desktop automatic install.

In the third question, all respondent said they never saw framework application "RPGMGMK" for game making on other places. They also gave suggestion to add chat feature.

\section{CONCLUSION}

Based on the gathered data, it indicated if both subject $45 \%$ of computer science students and $82 \%$ non-computer science students said it was very helpful using 'RPG Maker Game Makin Kit" as a supporting tool to game making for collaborative learning.

This indication strengthened the answer from both subjects; they mostly showed same respond in easy to use, features provided, and the installation of framework itself.

Accordingly, from the data, it showed that for computer science students especially Game Tech department that usually making game felt lots of easiness with RPGMGMK framework. Especially for non-computer science students of English literature department for first time making game in group said the framework were very helpful, because they did not need to know technical aspect like installation and automated file sharing by framework.

Available features in framework that ease the game development are file-sharing management, automatic RPG and Dropbox desktop installation.

\section{ACKNOWLEDGMENT}

I am very much obliged and very proud for the Excellent scholarship from Bureau for Planning and International Cooperation, the Indonesian Ministry of Education and Culture of Indonesia who believe that I deserve this scholarship. This scholarship is a great help for me to finish my study in due time.

\section{REFERENCES}

[1] Sudarman, "Penerapan Metode Collaborative Learning untuk Meningkatkan Pemahaman Materi Mata Kuliah Metodologi Penelitian," J. Soc. Sci., vol. 3, no. 1, pp. 94-100, 2003.

[2] M. Papastergiou, "Online Computer Games as Collaborative Learning Environments: Prospects and Challenges for Tertiary Education," J. Educ. Technol. Syst., vol. 37, no. 1, pp. 19-38, 2008.

[3] A. R. Christanti, R. Sanjaya, and C. T. Murniati, "Developing Educational Game for Collaborative Learning," Int. Semin. Appl. Technol. Inf. Commun. Indones., pp. 1-6, 2016. dictionary.cambridge.org, "Cambrigde dictionary." [Online]. Available: http://dictionary.cambridge.org/dictionary/englis h/framework. [Accessed: 26-Aug-2016].

[5] T. Lewis et al., "Object Oriented Application Frameworks," Manning Publ. Co., pp. 1-8, 1995.

[6] P. Terbaru and K. Terbaru, "Apa Itu Framework?," 2016. [Online]. Available: http://www.devaradise.com/id/2013/12/mengena 1-pengertian-framework-website.html.

[Accessed: 26-Aug-2016].

[7] I. Astuti, "Tinjauan Tentang Peran Unit Pelaksana Teknis (UPT) Pendidikan dalam Meningkatkan Pelayanan Pendidikan Di Kecamatan Muara Bengkal Kabupaten Kutai Timur," eJournal Ilmu Pemerintah., vol. 3, no. $2,2015$.

[8] UNESCO, Education for people and planet: Creating Sustainable Futures For All, Second Edi. Paris: the United Nations Educational, Scientific and Cultural Organization, 2016.

[9] S. A. Kalaian and R. M. Kasim, "A Metaanalytic Review of Studies of the Effectiveness of Small- Group Learning Methods on Statistics Achievement," J. Stat. Educ., vol. 22, no. 1, pp. 1-20, 2014. 
[10] M. Papastergiou, "Online Computer Games as Collaborative Learning Environments: Prospects and Challenges for Tertiary Education," J. Educ. Technol. Syst., vol. 37, no. 1, pp. 19-38, 2008.

[11] A. R. Christanti, C. T. Murniati, and R. Sanjaya, "Game Making Framework Development for Collaborative Learning," Thirteen. Int. Conf. eLearning Knowledge-Based Soc. Thail., 2016.

[12] J. R. Abanador, G. C. D. Buesa, G. M. L, and J. Mañibo, "Teaching Methods and Learning Preferences in the Engineering Department of an Asian University," Int. J. Acad. Res. Progress. Educ. Dev., vol. 3, no. 1, pp. 1-15, 2014.

[13] B. L. Smith and J. MacGregor, "What is Collaborative Learning?," Collab. Learn. A Sourceb. High. Educ., pp. 1-11, 1992.

[14] M. Dooly, "Constructing Knowledge Together," Telecollaborative Lang. Learn. A Guideb. to Moderating Intercult. Collab. Online, pp. 2145, 2008.

[15] D. Schaffhauser, "Will Gaming Save Education , or Just Waste Time?," THE Journal, pp. 1-5, 2013.

[16] D. Riehle and T. Gross, "Role model based framework design and integration," $A C M$ SIGPLAN Not., vol. 33, no. 10, pp. 117-133, 1998.

[17] B. A. Santoso, "Wawancara dengan Iskandar Soesman, Pria Dibalik Framework yang Membangun Situs Kompasiana," www.codepolitan.com. [Online]. Available: https://www.codepolitan.com/wawancaradengan-iskandar-soesman-pria-dibalikframework-yang-membangun-situs-kompasiana. [Accessed: 26-Aug-2016]. 